Henning Nolke*

\title{
Argumentationsanalyse. \\ Grundtræk af en modulær sprogvidenskabelig tilgang
}

\begin{abstract}
In this article, the author presents some fundamentals of a modular linguistic approach to argumentation. Argumentation is seen as a matter of interpretation, and since interpretation phenomena depend on linguistic material as well as on context in the broad sense, genuine linguistic theory should be an integrated part of argumentation theory. A linguistic approach to argumentation should adopt instructional semantics as opposed to representational semantics and argumentative (discourse dynamic) semantics as opposed to referential semantics. In view of the high complexity of argumentation phenomena, rigour can be obtained only in a strictly modular approach. After a brief overview of the global approach, the author lays down some fundamental methodological and theoretical principles for modular studies. He then introduces three modules taking care of Lexical Semantics (the Topos Theory), Polyphony and Argumentative Functors. The three mini-theories involved are all inspired by the Theory of Argumentation in Language developed by the French linguists Oswald Ducrot and Jean-Claude Anscombre. Two recommendations for practitioners are formulated as conclusion: "To be efficient, use the right linguistic forms and structures!" and "To choose efficient forms, keep your eye on the purpose!"
\end{abstract}

\section{Indledning}

Argumentationsteori beskæftiger sig oftest med strukturer på tekstniveau og i interaktion. Sproglige analyser inddrages kun sekundært i det omfang, de kan anvendes til at belyse disse overordnede strukturer og funktioner. $\mathrm{Nu}$ formidles argumentation jo gennem sprog, så det forekommer oplagt, at en egentlig sprogvidenskabelig analyse må kunne yde et væsentligt bidrag til vor forståelse af, hvad argumentation er, og hvordan den fungerer. Denne artikel indeholder et forslag til, hvorledes en sådan analyse kan gribes an.

* Henning Nølke

Fransk Institut

Handelshфjskolen i Århus

Fuglesangs Allé 4

DK-8210 Arhus V

Hermes, Journal of Linguistics no. 21 - 1998 
Udgangspunktet er en opfattelse af, at argumentation opstår som resultat af interpretationsprocessen. Hvilken argumentation modtager opfatter, afhænger direkte af, hvorledes han tolker det sproglige udtryk, der formidler argumentationen. (Hvorledes han dernæst reagerer på den - dvs. den persvasive effekt eller værdi - er så igen et andet spørgsmål.) $\mathrm{Nu}$ er det sådan, at interpretationsfænomener afhænger både af det sproglige materiale og af konteksten i bred forstand; og der er oplagt en sammenhæng mellem disse to komponenter.

Min hovedinteresse har altid været studiet af den sproglige forankring af interpretationen. For at forstå, hvordan argumentation virker, er sproglig analyse overordentlig vigtig; og dette gælder ikke bare viden om ordenes betydning, også strukturel viden kan være afgørende - på ytringsniveau såvel som på tekstniveau. Christa Thomsen (1998) giver i sin afhandling om forhandlingssprog et eksempel på en fransk dialog mellem en dansker og en franskmand, hvori ordet oui blev misforstået af den franske partner, der fejlagtigt tog det som en markering af, at den argumentative enhed blev afsluttet, medens afsender i virkeligheden blot planlagde en koncessiv struktur: oui ... mais ....

Sproglig analyse er imidlertid ikke nok i sig selv. Man er nødt til at anskue problemet ud fra en global opfattelse. Man må prøve at danne sig så præcis en idé som muligt om, hvorledes interpretationen fungerer i praksis. Spørgsmålet er imidlertid, hvorledes dette skal kunne lade sig gøre, når der er så mange analytiske niveauer involveret, så mange forskellige parametre at tage hensyn til. I min stræben efter stringens har jeg valgt en tilgang, der bygger på en skelnen mellem langue og parole på modelniveau. Et system af moduler tager sig af de forskellige aspekter af det rent sproglige bidrag til argumentationen og giver som output et sæt instrukser for interpretationsprocessen. Det er naturligvis et enormt projekt at ville analysere argumentation på denne måde. Ikke desto mindre vil jeg fors $\emptyset \mathrm{ge}$ at fremhæve nogle af grundtrækkene for en sådan analyse og give et par eksempler på, hvordan den kan fungere i praksis. Jeg vil koncentrere mig om nogle særlige sproglige markører eller - som jeg foretrækker at kalde dem - de argumentative funktorer. ${ }^{1}$

1 I Nølke (1992) benyttede jeg termen argumentative particles. Denne term er imidlertid uheldig, da mange af de størrelser, der fungerer på denne måde, er faste forbindelser og syntagmer, så jeg foreslår nu i stedet termen argumentative funktorer (på engelsk argumentative functors). Denne term fremhæver nemlig deres centrale karakteristika, som ligger i deres funktion og ikke i deres form. 


\section{Analyseniveauer}

Først må vi dog have et kort overblik over den overordnede tilgang. Lad os begynde med et simpelt eksempel:

(1) Hanne til Søren:

- Jeg har arbejdet hårdt hele dagen, så jeg synes virkelig, du skulle gå i teatret alene.

(1) er et eksempel på, hvad man kan kalde en mikroargumentation, dvs. en minimal argumentativ sekvens, som normalt vil være del af en mere omfattende argumentativ tekst. Den sproglige markør så angiver tydeligt, at det at Hanne har arbejdet hårdt hele dagen, skal opfattes som et argument for at foreslå Søren at gå alene i teatret. Men så er ikke den eneste sproglige størrelse, der er ansvarlig for denne effekt. Faktisk kan vi udelade dette ord og stadig få det samme argumentative resultat. Man kan sige, at så på en måde bare udnytter en eller anden form for argumentativt potentiale, der er der i forvejen. Valget af ordet arbejde kombineret med hårdt spiller oplagt også en rolle. Tilstedeværelsen af disse to ord får os til mere eller mindre at forudse den givne fortsættelse, især hvis vi befinder os i den konkrete situation, sætningen ytres i. På den anden side set afhænger den aktuelle argumentation, som den opfattes af modtager, afgørende af, hvorledes han interpreterer de involverede ord, og hans interpretation bygger ikke blot på det sproglige materiale, han hører (eller læser). Hans viden om afsender og alle mulige andre former for ekstrasproglig viden kan også spille ind. Han kunne fx ud fra Hannes første ytring (Jeg har arbejdet hårdt hele dagen) tro, at hun havde lyst til at gå $i$ teatret for at hvile ud efter en hård dag. I så tilfælde kommer den anden ytring som en slags overraskelse, der går imod hans forventning, og det kunne måske få Søren til at komme med en indvending som: "Men efter en lang dags arbejde er det, du virkelig har brug for, netop at gå i teatret og slappe af med et godt skuespil". Hannes brug af virkelig i konklusionen foruddiskonterer denne indvending. Dette adverbial indfører en polyfon nuance, der viser, at hun allerede har tænkt på det mulige modargument. Det er endelig værd at notere sig, at selv om man skulle have fuldkommen viden om situationen og de to aktører, ville ytringen alene ikke sætte os i stand til at forudsige noget som helst om Sørens faktiske reaktion, dvs. om argumentationens persvasive effekt.

Man kan drage nogle meget vigtige konklusioner fra dette simple eksempel. For det første det faktum, at argumentation hænger snævert 
sammen med interpretation. En komplet undersøgelse af (mikro)argumentation ville derfor kræve et studium af alle aspekter ved interpretationsprocessen. For det andet det faktum, at sproglig struktur har en central rolle i dette spil. Særlige ord er tilbøjelige til at introducere meget specifikke argumentative nuancer. Ikke blot skaber de det grundlæggende "argumentative materiale", de kan også agere direkte på forskellige argumentative tolkninger og dermed styre disse. I denne forstand lægger selve sproget begrænsninger på argumentationen (jf. Nølke 1992).

Argumentative studier lægger således op til sproglig analyse. Ikke alle sprogvidenskabelige tilgange synes dog lige egnede til formålet. Der er på dette punkt to teoretiske beslutninger, det forekommer mig specielt vigtigt at tage. Man bør anvende instruktionel semantik og ikke repræsentationel semantik, og man bør benytte sig af argumentativ semantik, således som denne er udviklet i Frankrig af Ducrot og Anscombre, og ikke referentiel semantik.

- Instruktionel semantik giver som output et sæt instrukser for interpretationen, hvorimod repræsentationel semantik producerer semantiske repræsentationer, som så holdes op mod virkeligheden i interpretationen. Derfor er instruktionel semantik bedre egnet til at tage højde for, hvad der sker under interpretationsprocessen.

- For argumentativ semantik er argumentation forstået som diskursdynamik selve den sproglige betydning, hvorimod referentiel semantik opfatter logisk struktur og referentielle egenskaber som grundlæggende.

Disse forskelle vil blive uddybet nedenfor.

Vi kan konkludere, at sproglig form og struktur relaterer sig direkte til interpretation og derfor til argumentation ved at indsnævre potentialet herfor. Emnet for denne artikel er netop disse sproglige begrænsninger på argumentation.

\section{Den modulære tilgang}

Jeg har andetsteds (Nølke 1994a) argumenteret for, at man i sprogvidenskab anvender en modulær tilgang og ikke en enstrenget teori. Jeg skal her resumere en sådan tilgangs vigtigste karakteristika. Lad mig straks understrege, at det ikke drejer sig om at konstruere endnu en mo- 
dulær grammatik eller lignende, men om at fastsætte nogle fundamentale metodologiske og teoretiske principper for modulære arbejder.

En modulær tilgang er grundlæggende en tilgang, der applicerer en teoretisk model, som består af et system af undersystemer kaldet moduler. Hvert modul kan opfattes som en miniteori, der består af regler med et begrænset problemområde som virkefelt. Modulerne er knyttet sammen af et system af metaregler, der artikulerer deres interaktion. Den helt grundlæggende idé bag en modulær tilgang er, at man aldrig må miste overblikket over, hvad man foretager sig. Ideelt set fremmer den modulære, teoretiske ramme opstillingen af koncise beskrivelser af sproglige fænomener, fordi det begrænsede antal koncepter og regler, der indgår i de enkelte moduler, gør det muligt at give præcise definitioner af de centrale begreber. Den åbner også en dør til forklaringsniveauet, fordi den muliggør en afdækning af systematiske relationer mellem fænomener, som er blevet defineret og beskrevet uafhængigt af hverandre. En tredje oplagt fordel ligger i, at opbygningen af modulerne kan trække kraftigt på indsigt, andre forskere har opnået i diverse teoretiske rammer. Undertiden kan hele teorier eller dele af teorier genfortolkes og integreres i den overordnede modulære model. Det er faktisk netop, hvad jeg vil gøre i denne artikel.

For at få en sådan model til at virke og for at undgå faren for at falde i den lokkende, naive eklekticismes fælde må den modulære tilgang efterleve en række metodologiske principper. Lad mig resumere nogle af de vigtigste. ${ }^{2}$ Først to metodologiske krav:

\section{Metodologiske krav:}

- Der skal sikres en gensidig uafhængighed mellem modulerne.

- Der bør etableres et homogent begrebsapparat, som gør det muligt at skabe præcise forbindelser mellem modulerne.

Den gensidige uafhængighed er afgørende for systemets forklaringskraft, og en vis begrebsmæssig homogenitet er nødvendig for at få interaktionen mellem modulerne til at fungere. På den anden side set bør der ikke a priori lægges derivationelle begrænsninger på systemet. Om systemet (eller dele af det) skal underlægges en derivationel rækkefølge eller ej, er et empirisk spørgsmål. Et modulært system er nemlig i stadig

2 I Nølke (1994a) findes en grundig gennemgang af de metodologiske aspekter. 
udvikling, og dets udformning bør styres af to metodologiske principper, der går i hver sin retning:

\section{Metodologiske principper:}

- Princippet for teoretisk økonomi: Alt andet lige bør man altid søge den teoretisk simpleste løsning.

- Princippet for dialektisk forbindelse mellem teori og data: Det enkelte forskningsprojekts formål er altid afgørende for de teoretiske valg, der træffes.

Det første princip er i virkeligheden en variant af Ockhams berømte ragekniv, og det andet indskriver sig i Poppersk filosofi.

Lad os nu se på, hvordan man kan applicere en modulær teoriopbygning på (sprogvidenskabelig) argumentationsanalyse. Den grundlæggende idé er altså at konstruere en model, der giver instrukser for interpretationen. Med dette for $\varnothing j$ je vil jeg foreslå tre moduler, som tilsammen skulle være i stand til at tage sig af de fleste sproglige argumentationsmarkører, man støder på. For at danne sig en idé om, hvorledes argumentation rent faktisk fungerer, må man imidlertid også konstruere en eller anden form for interpretationsmodel. Hovedideen bag sådan en model er, at de sproglige komponenter genererer et input, der indeholder mange forskellige instrukser, som hver især overvejende består af mængder af individer og relationelle variabler tilkoblet mere eller mindre præcise instrukser vedrørende deres instantiering. Et væsentligt særtræk er konceptet afsenderversion. Det er nemlig sådan, at afsender ikke bare ved hjælp af fx intonation kan komme med anvisninger mht., hvorledes hans ytring skal tolkes, han kan også arbejde videre på en formodet interpretation, allerede før modtager har haft nogen som helst chance for at gribe ind. Dette er faktisk yderst almindeligt forekommende, og vi skal se eksempler på det nedenfor. ${ }^{3}$

Følgende tre moduler vil blive anvendt: toposteorien, polyfoniteorien og et kompositorisk modul. Systemet bygger på Ducrot og Anscombres Teori om Argumentation i Sproget (TAS), som delvis ombygges og genfortolkes for at passe ind i den modulære model. I forbindelse med introduktionen af modulerne foreslår jeg nogle analy-

3 I Nølke (1994a: kap.II) findes et fuldt udviklet forslag til en interpretationsmodel, der følger disse principper. 
ser for at illustrere, hvorledes modellen fungerer. Disse analyser vil lejlighedsvis på uformel vis inddrage andre lingvistiske moduler. Allerførst vil jeg dog give en kort indføring til TAS. ${ }^{4}$

\section{Teorien om Argumentation i Sproget (TAS)}

Lige siden begyndelsen af halvfjerdserne har de to franske sprogforskere Oswald Ducrot og Jean-Claude Anscombre arbejdet på udviklingen af en ikke-referentiel semantik, der opfatter argumentativitet som sprogets grundlæggende betydning. Teorien om Argumentation i Sproget (TAS) ${ }^{5}$ adskiller sig radikalt fra klassisk, logisk orienteret semantik, der går ud fra, at sprogets referentielle egenskaber er basale, og som derfor bygger på den opfattelse, at semantisk teori grundlæggende bør beskæftige sig med sandhedsbetingelser. I TAS er instrukser, der vedrører diskursdynamikken således mere basale end referentielle instrukser, der peger ud af sproget. Forfatterne anfører, at man konstruerer repræsentationer af verden med henblik på at støtte argumentationen og ikke omvendt. ${ }^{6}$ Det er da også velkendt, at man kan præsentere

4 Man finder en grundig diskussion af TAS med alle de grundlæggende spørgsmål, teorien rejser og behandler, i Ducrot og Anscombres forskellige skrifter, i Bruxelles et. al. (1995) og i Raccah (1995a).

5 Teorien har skiftet navn flere gange undervejs. Man kan skelne tre hovedfaser. Først talte forfatterne om Integreret Pragmatik (la Pragmatique Intégrée) for at gøre det klart, at teorien beskæftigede sig med fænomener, der var integreret i sproget, men som ikke havde noget som helst med sandhedsbetingelser at gøre, og som derfor var pragmatiske ifølge den logiske tradition. Derpå blev teorien omdøbt til Radikal Argumentativisme (l'Argumentativisme Radical) for at understrege, at argumentativitet var primær og den deskriptive funktion blot sekundær. I dag, hvor teorien er blevet yderligere udviklet, kaldes den simpelthen Teorien om Argumentation i Sproget (la Théorie de l'Argumentation dans la Langue). I denne artikel tages der ikke højde for den allernyeste udvikling af TAS. Det er varianten fra midt i halvfemserne, der appliceres for at illustrere min hovedpointe, nemlig at argumentationsanalyse systematisk bør inddrage egentlig lingvistisk analyse.

6 Dette synspunkt står i skærende kontrast til Poppers filosofi. Popper hævder at "The argumentative function of human language presupposes the descriptive function: arguments are, fundamentally, about descriptions; they criticize descriptions from the point of view of regulative ideas of truth, content, and verisimilitude" (Popper 1972: 119). Som det fremgår af dette citat, er Poppers ræsonnement delvist cirkulært. Han tager for givet, at sproget grundlæggende er referentielt, og hvis det er tilfældet, ja så er den beskrivende funktion naturligvis mere grundlæggende end den argumentative. Hvad Popper taler om her, er imidlertid udelukkende argumentation, der bygger på ræsonneren; men det er, som det vil fremgå af det følgende, blot en særlig og i en vis forstand afledt form for argumentation. 
den verden, man taler om, på mange forskellige måder. Vores tale bedømmes langt fra altid på basis af, om det, vi siger, er sandt eller ej. Oftest har vi ingen direkte adgang til referentiel verifikation, og vore påstande egner sig ikke altid til at blive beskrevet ved hjælp af termerne sand/falsk. Det er faktisk sådan, at vi, når vi taler, vælger repræsentationer af verden, der passer til vore (argumentative) formål - vi "konfigurerer" verden -, og denne fremgangsmåde er først og fremmest et spørgsmål om at præsentere fakta i et positivt eller negativt lys. I denne forstand kan man med Ducrot og Anscombre sige, at god og dårlig er mere basale begreber end sand og falsk.

I denne tilgang er der mindst fire begreber, der skal holdes omhyggeligt ude fra hinanden, nemlig argumentativitet, argumentation, ræsonneren og persvasion. Følgende eksempel fra Ducrot (1990: 145ff, her i min oversættelse) illustrerer forskellene:

(2) A: Jeg foreslår, at du går til universitetet.

$\mathrm{B}_{1}$ : Der er langt.

$\mathrm{B}_{2}$ : Der er langt; men jeg holder meget af at gå.

$\mathrm{A}_{1}$ : Der er langt; men det er godt for helbredet at gå.

$\mathrm{B}_{1}$ 's svar kan kun opfattes som pegende på en negativ reaktion på A's forslag. Og det er endda tilfældet, selv om vi fx skulle vide, at B er en fanatisk tilhænger af at gå. Argumentativiteten af "Der er langt" er således negativ i denne kontekst. Det betyder imidlertid ikke nødvendigvis, at B er i gang med at argumentere for et afslag på opfordringen. Det er klart, at han kan udnytte den negative argumentativitet til en sådan argumentation; men som det fremgår af $\mathrm{B}_{2}$ 's svar, kan han også integrere den i en koncessiv struktur, som argumenterer for at acceptere forslaget. Det er nemlig sådan, at argumentationen først opstår i det øjeblik, afsender tager ansvaret for argumentativiteten. I B $\mathrm{B}_{1}$ 's svar, hvor "Der er langt" står alene, opfattes dette svar alt andet lige som dækkende $\mathrm{B}_{1}$ 's mening, og derfor vil det snarest opfattes som argumenterende for et afslag.

Medens argumentativitet således er den semantiske værdi og argumentation en handling, der afhænger af, om afsender tager ansvaret for argumentativiteten eller ej, så vedrører persvasion den intenderede virkning på modtager. Persvasion kan skabes med alle mulige slags virkemidler. Selvfølgelig også med argumentation. Hvis ytringen $\mathrm{A}_{1}$ således er en reaktion på $\mathrm{B}_{1}$, kan den bruges til at (forsøge på at) overtale 
B til at gå til universitetet på trods af hans første afslag. Eksemplet illustrerer en afgørende forskel på argumentation og persvasion. Det er kun anden del af ytringen $A_{1}$, der argumenterer for den positive reaktion; men den persvasive virkning afhænger lige så meget af første del. Ja, faktisk har persvasionen langt mindre chance for at lykkes uden denne første del. Koncession kan i virkeligheden opfattes som en særlig persvasiv strategi, og fortjener som sådan at blive undersøgt i sig selv.

Endelig er ræsonneren, fuldkommen lige som persvasion, ikke direkte forbundet med sprogbrugen. Ræsonneren kan karakteriseres som en mental proces, der tager information som input. Et eksempel, der er inspireret af en diskussion i Ducrot (1980: 9), illustrerer, at ræsonneren ikke afhænger af argumentativitet. Lad os antage, at man gerne vil have nogle oplysninger om H.C. Andersens værker, og man får at vide, at følgende to påstande er sande:

(3) Søren har læst nogle af H.C. Andersens værker.

(4) Hanne har ikke læst alle H.C. Andersens værker.

Hvem vil man så være tilbøjelig til at spørge, Søren eller Hanne? Sandsynligvis Hanne. Denne beslutning er resultatet af et ræsonnement, der tager sit udgangspunkt i påstandenes informative (kvantitative) værdier. Sandsynligvis vil man ræsonnere noget i retning af: "At have læst nogle værker betyder sandsynligvis at have læst nogle få værker”, og "ikke at have læst alle betyder sandsynligvis at have læst noesten alle". Ud fra dette ræsonnement deducerer man, hvem det er bedst at spørge til råds. Argumentativiteten i de to påstande går imidlertid i stik modsat retning, som det fremgår, hvis man ser nærmere på, hvorledes man kan fortsætte diskursen:

(3’) J Søren har læst nogle af H.C. Andersens værker, så han kan måske svare dig.

(4’) L Hanne har ikke læst alle H.C. Andersens værker, så hun kan måske svare dig.

(4') lyder faktisk ret underlig (det er det, symbolet L angiver). Testen viser, at argumentativiteten i (3) er orienteret mod 'alle', medens den i (4) er orienteret mod 'ingen', dvs. lige det modsatte af det resultat, der kom ud af ræsonneren (og deduktion). Eksemplerne kan også bruges til at vise, at persvasion kan gå imod argumentation, så at sige. Man kan nemlig sagtens forestille sig en situation, hvori de to påstande i (3) og (4) bruges med den persvasive intention at tilskynde modtager til at 
spørge Hanne snarere end Søren. Persvasion tager således sit udgangspunkt i ræsonneren snarere end i argumentation.

Vi kan konkludere, at ræsonneren som her defineret ligger tæt på den opfattelse af argumentation, man finder i de referentielt orienterede tilgange. ${ }^{7}$ De to forskellige opfattelser af argumentation kan illustreres således:

\begin{tabular}{lccc} 
Sproget & $\mathrm{X}$ & $\hat{\mathrm{A}}$ & $\mathrm{Y}$ \\
& $\downarrow$ & & $\downarrow$ \\
\hline Virkeligheden & $\mathrm{F}_{1}$ & $\rightarrow$ & $\mathrm{F}_{2}$
\end{tabular}

$\mathrm{X}$ og $\mathrm{Y}$ er sproglige udtryk og $\mathrm{F}_{1}$ og $\mathrm{F}_{2}$ fakta, begivenheder eller, hvad $\mathrm{X}$ og $\mathrm{Y}$ end måtte referere til i virkeligheden. Som det fremgår af figuren, passerer argumentation illustreret med symbolet $\hat{\mathrm{A}}$ direkte fra $\mathrm{X}$ til Y uafhængigt af virkeligheden, medens ræsonneren, her symboliseret med $\rightarrow$ bygger på en formodet relation i virkeligheden mellem $F_{1}$ og $F_{2}$. Det er denne ekstrasproglige relation, der sætter os i stand til at ræsonnere fra $\mathrm{X}$ til Y.

De følgende afsnit giver flere illustrationer af, hvorledes TAS fungerer.

\section{Leksikalsk semantik: Toposteorien}

Leksikalsk (argumentativ) semantik beskæftiger sig udelukkende med argumentativitet. Fra et argumentativt synspunkt falder leksikalske størrelser i to klasser, nemlig leksikalske ord og argumentative funktorer $^{8}$ (som jeg tager op i afsnit 7.). Leksikalske ord er først og fremmest substantiver og verber. Deres inhærente betydning består af topoi(bundter), hvor et topos består af to topiske (stort set det samme som konceptuelle) felter, ${ }^{9}$ en antecedent og en konsekvent. Leksikalsk betydning opbygges således af sæt af postulater om, hvorledes koncep-

7 Se også forrige note.

8 Denne dikotomi (som er min egen tolkning af TAS) er delvis parallel med den traditionelle skelnen mellem leksikalske og grammatiske ord; men kun delvis. Således er adverbier og adjektiver funktorer. Man må selvfølgelig også forvente, at der er nogle forskelle, eftersom "argumentativ grammatik" er fundamentalt forskellig fra traditionel grammatik.

9 Det er kun muligt her at gengive toposteoriens vigtigste aspekter. En grundig indføring i teorien kan findes i Bruxelles et al. (1995). 
tuelle felter er indbyrdes relaterede. Deres struktur involverer altid gradation. De har følgende form:

(6) 'jo mere (eller mindre) det ene felt er involveret, jo mere (eller mindre) er det andet felt involveret'

At bruge et ord om et givet objekt eller en given situation er at postulere at bestemte diskurstyper er mulige og naturlige som opfølgning af dette ord, medens andre diskurstyper ville være mindre sandsynlige eller udelukkede. Således kan man forestille sig, at betydningen af verbet at arbejde inkluderer et topos som:

(7) (Betydningen af at arbejde):

'jo mere man arbejder, jo mere træt bliver man'

Dette topos ville forklare, hvorfor sekvenser som:

(8) a. Jeg har arbejdet hele dagen, så jeg er trat.

b. Er du trat? - Ja, jeg har arbejdet hele dagen.

føles som ekstremt naturlige, medens sekvenserne i (9):

a. Jeg har arbejdet hele dagen, så jeg er ikke spor trat.

b. Er du trat? - Nej overhovedet ikke, jeg har arbejdet hele dagen.

føles ret underlige. Denne leksikalske analyse af at arbejde, som var et af toposteoriens første eksempler, forklarer, hvorfor at arbejde har den effekt, vi bemærkede i diskussionen af det første eksempel i afsnit 2.:

(1) Hanne til Søren:

- Jeg har arbejdet hårdt hele dagen, så jeg synes virkelig, du skulle gå i teatret alene.

Hanne benytter her det, at hun har arbejdet hårdt hele dagen, som argument for ikke at gå med Søren i teatret. Hvis at arbejde betyder at være træt, forklares dette umiddelbart. Imidlertid er det, som vi så, ikke vanskeligt at forestille sig en situation, hvori det, at Hanne har arbejdet hårdt hele dagen, snarere er et argument for den modsatte konklusion, dvs. for at gå i teatret. Denne virkning er det vanskeligere at forklare ud fra Hannes træthed; og en sekvens som:

(10) Jeg er så glad, jeg har arbejdet hårdt hele dagen.

udelukker helt en sådan forklaring.

Iagttagelser af denne art har fået toposteoriens fædre til at skelne omhyggeligt mellem intrinsekke og ekstrinsekke topoi. Ekstrinsekke topoi kan nås fra de intrinsekke topoi via topoikæder. Ordbetydning 
består af intrinsekke topoi, og disse er af en sådan natur, at ethvert tænkeligt ekstrinsekt topos kan forklares som en ekstrapolation af de intrinsekke topoi. Det intrinsekke topos knyttet til at arbejde kunne således tænkes at være noget $\mathrm{i}$ retning af 'jo mere arbejde, jo mere indsats/anstrengelse'. Faktisk kan megen indsats/anstrengelse meget vel både føre til træthed, som i det første eksempel, og til glædesfølelse som i (10).

Det er vigtigt at bemærke, at topoi kan appliceres med større eller mindre styrke. Således er det at arbejde hårdt i en vis forstand 'mere arbejde' end blot det at arbejde. Derfor er det, at Hanne har arbejdet hårdt, et stærkere argument for de konklusioner, hun måtte ønske at drage, end det, at hun blot har arbejdet, ville være i sig selv. Toposteorien udtrykker dette ved at sige, at hårdt signalerer, at de af verbet at arbejde aktiverede topoi skal appliceres med større styrke, end de skulle have været, hvis dette adjektiv ikke havde været brugt (se også afsnit 7.).

Lad os kort resumere. Argumentativitet bygger på topoi. Ord indeholder intrinsekke topoi, hvorfra mange forskellige ekstrinsekke topoi kan udledes ved hjælp af topoikæder. De intrinsekke topoi kan genkendes ved, at intet andet topos kan klemmes ind mellem deres antecedent og deres konsekvent. Dette synes faktisk netop ikke muligt mellem 'arbejde' og 'indsats/anstrengelse'. Topoi kan også afsløres ved hjælp af forskellige tests, der involverer argumentative funktorer. Vi vender tilbage til dette emne i syvende afsnit.

\section{Polyfoni}

Men først må vi se nærmere på polyfoniteorien. ${ }^{10} \mathrm{Vi}$ har set, at argumentationen opstår ved at afsender tager ansvaret for argumentativiteten, dvs. for de topoi han henviser til i sin tekst; men vi har også set, at han kan komme med andre synspunkter uden at gøre dem til sine egne. Det så vi fx i (2)A $\mathrm{A}_{1}$ :

(2) (A: Jeg foreslår, at du går til universitetet.

$\mathrm{B}_{1}$ : Der er langt.)

$\mathrm{A}_{1}$ : Der er langt; men det er godt for helbredet at gå.

10 Jeg vil kun bruge polyfoniteorien som en slags begrebsramme, så jeg vil nøjes med at præsentere de væsentligste af de ideer, den bygger på. Man kan finde en grundigere indføring i Ducrot (1984: kap.VIII) og i Nølke (1994a). 
hvor han tager $\mathrm{B}_{1}$ ' synspunkt $\mathrm{i}$ sin mund uden at tage ansvaret for dets argumentativitet. Det er et eksempel på polyfoni.

Det originale ved polyfoniteorien er, at den opløser enhedsopfattelsen af afsenderbegrebet. Den grundlæggende idé bag teorien er, at hver enkelt ytring kan indeholde adskillige "krystalliserede" dialoger (som i (2) $\left.\mathrm{A}_{1}\right)$. Mere præcist sagt består en ytrings betydning af, at flere elementærdiskurser er indlejret i hinanden. Pointen er, at andre synspunkter end afsenders kan være til stede på denne måde, og at disse individuelle synspunkter endda kan være angivet på sætningsniveau, dvs. ved hjælp af det rent sproglige materiale. Polyfoni er et sproginhærent fænomen for så vidt som sproget giver instrukser mht. dets polyfone interpretation. Nægtelsen er det kanoniske eksempel:

(12) Denne væg er ikke hvid.

Man har en klar fornemmelse af, at denne ytring kommunikerer to ( $\mathrm{u}-$ forenelige) synspunkter. Når afsender har benyttet sig af nægtelsen $i k k e$, er det fordi nogen måske mener (eller kunne have ment), at væggen faktisk er hvid, en opfattelse afsender ikke deler. Med henblik på at formalisere denne iagttagelse vil vi sige, at nægtelsen (ikke) skaber en polyfonistruktur i sætningen, som består af to (her uforenelige) synspunkter:

(12) $\mathrm{s}_{1}:$ Denne væg er hvid

$\mathrm{s}_{2}$ : $\quad \mathrm{s}_{1}$ er en fejltagelse

Man kan finde empiriske argumenter for, at disse to synspunkter er til stede allerede på sætningsniveau, ved at se på, hvorledes man kan fortsætte diskursen efter (12):

(13) a. [(12)], og det ved du udmærket godt.

b. [(12)]; det tror min nabo ellers.

c. [(12)]; tværtimod (den er kulsort).

Medens a. knytter an til $s_{2}$, tager b. og c. deres udgangspunkt i $s_{1}$. Pointen er, at disse to forankringspunkter for den fortsatte diskurs ikke ville eksistere i en ytring uden nægtelsen. Så vi kan konkludere, at nægtelsen skaber en polyfonistruktur i sætningen på langue-niveau.

Det er meget interessant at bemærke, at afsender kan knytte direkte an til et synspunkt, han selv eksplicit har taget afstand fra. Det er tilfældet i (13b.) og (13c.). Det er også værd at bemærke, at medens vi ved fra ytringen i (12), hvem der er ansvarlig for $\mathrm{s}_{2}$ (det er afsender), kan vi ikke sige noget om, hvem der måtte være knyttet til det andet synspunkt 
$\left(\mathrm{s}_{1}\right)$. Alt hvad vi ved er, at det ikke er afsender, ${ }^{11}$ og det bliver et centralt anliggende $\mathrm{i}$ interpretationsprocessen at fors $\emptyset g e$ at forankre dette andet synspunkt, også selv om denne forankringsrelation naturligvis sagtens kan forblive uspecificeret.

Nægtelsen er blot et blandt mange eksempler på, at en sproglig størrelse indfører en polyfonistruktur. Mange morfo-syntaktiske strukturer har denne egenskab. Faktisk har vi allerede set, at konjunktionen men fungerer således $\mathrm{i}(2) \mathrm{A}_{1}$, og adverbialet virkelig har en lignende funktion i eksempel (1). Polyfoniteoriens hovedinteresse ligger netop i det faktum, at den muliggør en formalisering af alle disse nuancer, som sætter os i stand til at forklare mange relationer mellem ytringens form, dvs. dens polyfonistruktur (langue-niveau), og dens interpretation, som afdækker dens polyfonikonfiguration (parole-niveau). ${ }^{12}$ Afsender kan nemlig præsentere adskillige synspunkter i en enkelt ytring, og han kan etablere hele serier af relationer mellem disse synspunkter på den ene side og forskellige diskursindivider (deriblandt ham selv) på den anden. Det bliver så et afgørende moment af interpretationsprocessen at afdække disse relationer, hvilket er det samme som at afsløre kommunikationsparternes relevante identiteter og dermed den anvendte argumentations raffinementer.

Det er netop det polyfone spil, der ligger bag argumentationens dukken op. Hvert eneste synspunkt indeholder en bid argumentativitet og under interpretationsprocessen forsøger modtager automatisk at forankre denne argumentativitet, idet han især prøver at forstå, hvilken argumentativitet afsender selv tager ansvaret for og hvilken ikke. Derved fremtolker modtager ytringens polyfonikonfiguration, som så genererer den argumentative handling, dvs. argumentationen.

Lad os resumere. Som vi så ovenfor, defineres argumentativitet i TAS som bestående af topoi(bundter). At forstå argumentationen er således det samme som at forstå, hvem der tager ansvaret for hvilke topoi - som altid ifølge selve ytringen. Polyfonimodulets centrale opgave i argumentationsanalysen er følgelig at afdække polyfonistrukturen, som er bygget op af synspunkter, og at afsløre de sproglige instrukser, der gives for dennes omdannelse til polyfonikonfiguration. Omdannelsen

11 I en særlig (markeret) kontekst kan det endda være en (tidligere) instans af afsender som i: "Tja, faktisk er væggen ikke hvid".

12 Det er Hans Kronning, der har foreslået denne term (mundtlig kommunikation). 
består i det væsentlige af en instantiering af de involverede variabler, som følger de instrukser, det sproglige materiale har givet for instantieringen.

\section{Argumentative funktorer ${ }^{13}$}

I argumentativ semantik grupperer de leksikalske størrelser sig, som vi så det i afsnit 5, i to klasser, nemlig leksikalske ord og argumentative funktorer. Leksikalske ord har inhærent betydning, der består af topoi (jf. afsnit 5). I kontekstualiseringsprocessen modificeres de applicerede topoi og kombineres i en (polyfon) argumentativ (makro)struktur, som så derpå afføder argumentative handlinger. I denne proces spiller de argumentative funktorer en særlig regulerende og organiserende rolle. De udfører modifikation, selektion, specifikation og kombination. De kan efter deres hovedfunktion opdeles i tre delvist overlappende klasser: modifikatorer (hovedsagelig modifikation), operatorer (hovedsagelig selektion) og konnektorer (hovedsagelig specifikation og kombination).

\subsection{Modifikatorer ${ }^{14}$}

Modifikatorerne modificerer den styrke, topoiene appliceres med. De fleste modifikatorer er adjektiver eller (verbal)adverbier. Man kan adskille to hovedtyper: realiserende modifikatorer og afrealiserende modifikatorer. ${ }^{15}$ Som modifikatorer afhænger deres funktion helt og holdent af værtsordet, som indeholder det berørte topos. De defineres derfor relativt til deres værtsord:

Ordet $\mathrm{Y}$ er en Realiserende Modifikator (RM) i forhold til ordet X, hvis og kun hvis kombinationen XY har samme argumentative retning som X og større argumentativ styrke end $\mathrm{X}$ alene.

13 Dette modul har en særlig status i den overordnede model, derved at det kræver et specificeret input; men det kan ikke på nogen måde opfattes som et "slut"modul i en eller anden form for derivationsprocedure. Systemet er basalt set ikke-derivationelt instrukser fra alle moduler interagerer i konstruktionen af teksten. Det betyder at output fra et hvilket som helst modul a priori kan bruges som input i et hvilket som helst andet modul. Se også afsnit 2.

14 Dette afsnit bygger især på Ducrot (1995) og Raccah (1995b).

15 Garcia (1995) har opdaget en tredje type, nemlig de overrealiserende modifikatorer. De peger på et ekstremt punkt på en skala og bevirker altid, at der opstår en eksklamativ nuance som i: Der er en lфsning; men den er FANTASTISK!. 
Ordet Y er en Afrealiserende Modifikator (AR) i forhold til ordet X, hvis og kun hvis kombinationen $\mathrm{XY}$ enten har modsat argumentativ retning af $\mathrm{X}$ eller mindre argumentativ styrke end $\mathrm{X}$ alene.

Man kan bruge de to konnektorer men og endda i tests til at afdække modifikatorerne. Men kan nemlig kun kombinere to modsatrettede argumentative retninger, og endda markerer altid en ensrettet, men stærkere argumentativitet. Vi kan således konstruere følgende testpar:

(14) a. '... X, men XY' er underlig ( $\mathrm{L}$ ), hvis Y er en RM i forhold til X, og udmærket ( $\mathrm{J}$ ), hvis Y er en AM (i forhold til $\mathrm{X}$ ).

b. '... X, og endda XY er udmærket ( $\mathrm{J}$ ), hvis Y er en RM i forhold til X, og underlig ( $\mathrm{L}$ ), hvis Y er en AM (i forhold til $\mathrm{X})$.

Eksemplerne i (15) illustrer testene:

(15) a. L Søren er en slægtning, men en nær slægtning.

b. J Søren er en slægtning, og endda en nær slægtning.

c. J Søren er en slægtning, men en fjern slægtning.

d. L Søren er en slægtning, og endda en fjern slægtning.

Tegnet $\mathrm{J}$ symboliserer, at afsender kan ytre sekvensen helt naturligt uden i øvrigt at have nogen speciel grund til at holde X og XY op mod hinanden, og tegnet $\mathrm{L}$ symboliserer, at han ikke kan gøre dette. Således kan (15a.) selvfølgelig ytres under særlige omstændigheder, som fx hvis vi skal bruge en slægtning til et job, som vi imidlertid af en eller anden grund ikke har lov til at bruge for nære slægtninge til. Så får vi argumentationen i (16):

(16) 'Søren er en slægtning ( $\hat{A}$ så ham kan vi bruge); men han er en nær slægtning ( $\hat{A}$ så vi kan alligevel ikke bruge ham)'.

Som det fremgår, kan (15a.) kun bruges i sammenhænge, hvor det at være slægtning og det at være nær slægtning er argumentativt modsatrettet. Testen viser, at nor er en RM i forhold til slagtning, medens fjern er en AM. Populært sagt viser testen altså, at argumentativt set er en nær slægtning (normalt) på en eller anden måde en mere eller bedre slægtning, end en fjern slægtning er det. (17) viser endnu et par eksempler:

(17) a. Der er en løsning; men den er J vanskelig/L let.

b. Der er en løsning; og den er endda L vanskelig/J let.

c. Der er et problem; men det er L vanskeligt/J let.

d. Der er et problem; og det er endda J vanskeligt/L let. 
Eksemplerne viser, at et givet adjektiv kan være RM i forhold til et substantiv og AM i forhold til et andet. Som man ser, er vanskelig RM i forhold til problem og AM i forhold til lфsning, og mht. let er det nøjagtig modsat.

En meget væsentlig forskel mellem de to typer skjuler sig i det faktum, at RMer altid bevarer den argumentative retning, medens AMer vender den i nogle kontekster og bevarer den i andre. I sidstnævnte tilfælde reducerer de styrken. AMerne er altså kontekstsensitive, medens RMerne ikke er det. Syntaksen kan have en afgørende indflydelse. Således synes adjektiverne i dansk at være svækkere, når de står attributivt, og vendere, når de står prædikativt:

(18) a. J Der er en forbedring; det er godt.

b. L Der er en forbedring; det er skidt.

(19) a. J Der er en forbedring; men det går langsomt.

b. L Der er en forbedring; og det går endda langsomt.

(20) a. J Der er en langsom forbedring; det er godt.

b. L Der er en langsom forbedring; det er skidt.

(21) a. L Forbedringen er langsom; det er godt.

b. J Forbedringen er langsom; det er skidt.

(18) viser, at forbedring indeholder det elementære topos < FORBEDRING ; GOD > 16, og (19) viser, at langsom er AM i forhold til forbedring. (20) viser så, at langsom som attributiv faktisk bevarer den argumentative retning (det er en svækker), og (21) viser, at samme adjektiv brugt prædikativt vender den (det er en vender). Ducrot (1995: 152) nævner, at denne forskel synes at have at gøre med, hvorvidt afsender tager argumentativiteten fremkaldt af AMen på sin egen kappe eller ej. Med andre ord afhænger langsoms funktion af polyfonistrukturen. Når afsender selv tager ansvaret, bliver AMen en vender. Faktisk kan det vises, at disse aspekter af polyfonistrukturen kan afledes direkte af de syntaktiske fokaliseringsregler, jeg har udviklet i Nølke (1994a, b), for så vidt som segmenter, der er markeret som tilhørende fokaliseringsdomæner formidler afsendersynspunkter (som en meget stærk defaultværdi). Vi står altså her over for et interessant eksempel på et fænomen, som ved første øjekast kan virke forvirrende, men som falder nydeligt på plads i en modulær tilgang, der systematisk kombinerer regler

16 Topoi, hvori konsekventen er en af de elementære værdier 'god' eller 'dårlig', kaldes elementære topoi. 
fra forskellige moduler. Jeg vil imidlertid ikke uddybe dette emne yderligere i denne artikel.

\subsection{Operatorer}

Operatorerne selekterer blandt de disponible topoi, eller rettere blandt de topiske former. De fleste medlemmer af denne klasse er adverbier eller partikler. Lad os først se på et forholdsvis simpelt eksempel inspireret af Anscombre (1989: 27ff) ${ }^{17}$ og gentaget fra Nølke (1992):

(22) a. Du skulle tage og købe denne dims, den koster $100 \mathrm{kr}$.

b. Lad være med at købe denne dims, den koster $100 \mathrm{kr}$.

c. Du skulle tage og købe denne dims, den koster kun $100 \mathrm{kr}$.

d. Lad være med at købe denne dims, den koster kun 100 kr.

I en helt naturlig læsning aktualiserer alle disse ytringer det samme topossystem (hvor $\mathrm{P}$ = 'billig' og $\mathrm{Q}$ = 'være tilbøjelig til at købe'):

(23) a1. Jo billigere en dims er, jo mere tilbøjelig er man til at købe den. $[<+\mathrm{P},+\mathrm{Q}\rangle]$

a2. Jo dyrere en dims er, jo mindre tilbøjelig er man til at købe den. $[\langle-\mathrm{P},-\mathrm{Q}\rangle]$

b1. Jo billigere en dims er, jo mindre tilbøjelig er man til at købe den. $[<+\mathrm{P},-\mathrm{Q}\rangle]$

b2. Jo dyrere en dims er, jo mere tilbøjelig er man til at købe den. $[<-\mathrm{P},+\mathrm{Q}\rangle]$

Alligevel er der en væsentlig forskel i den måde, de fire ytringer i (22) selekterer deres topoi på. Alle fire topoi er således forenelige med de to første ytringer (22a.) og (22b.). Mere præcist udtrykt kan (22a.) takket være dens første sætning vælge enten a1. eller b2., idet valget afhænger af, om $100 \mathrm{kr}$. i denne sammenhæng opfattes som billigt eller dyrt; men ytringen vil samtidig acceptere disses konverse topoi (henholdsvis a2. og b1.); og (22b.) kan vælge enten a2. eller b1., samtidig med at den accepterer disses konverse topoi. De to sidste ytringer, (22c.) og (22d.) foretager imidlertid en klar selektion: (22c.) selekterer a1. (og accepterer dets konverse a2.), og (22d.) selekterer b1. (og accepterer dets konverse b2.). Det kan kun skyldes tilføjelsen af ordet kun. Vi kan følgelig konkludere, at denne operator selekterer de topoi, der involverer begrebet billighed. Mere generelt synes kun altid at selektere de topoi, der intui-

17 I min oversættelse. Anscombre giver en grundigere analyse af disse eksempler. 
tivt føles som den negativt orienterede egenskab, en virkning der er særlig iøjnefaldende, når denne operator arbejder på kvantitative gradueringer som i dette tilfælde.

Ducrot har for nylig vist (1995: 156), at den franske ækvivalent til kun, ne...que, i dens kvalitative anvendelse kun kan kombineres med AMere, og at den så gennemtvinger en inversionslæsning (den bliver en vender). Det er præcist, hvad man skulle forvente, for så vidt som ne...que er en fokuspartikel og derfor markerer AMen som fokus (jf. ovenfor). Der er dog nok på dette punkt en forskel mellem den franske operator ne...que og den danske kun. I modsætning til ne...que synes kun nemlig kun i stand til at vende til en negativ retning som i ovenstående eksempler. Hvis jeg har ret i det, bidrager denne iagttagelse med (yderligere) stof til interessante komparative studier.

Ytringerne i (24) giver eksempler på en anden type operator, nemlig for:

(24) a. L Du skulle tage og købe denne dims, den er for dyr.

b. J Lad være med at købe denne dims, den er for dyr.

c. L Du skulle tage og købe denne dims, den er for billig.

d. J Lad være med at købe denne dims, den er for billig.

Begge operatorer, kun og for er syntaktisk tilknyttet topos'ets antecedent, og de selekterer begge en negativ retning; men medens kun baserer sin selektion på antecedenten, arbejder for på konsekventen og selekterer her den negative variant. Ved første øjekast kan det se ud, som om for har meget komplekse argumentative karakteristika; men man kan vise, at den selektion, den udfører, er dens helt fundamentale egenskab:

(25) a. (J ) Der er en forbedring; men den er for langsom. Det er $\mathrm{J}$ skidt/L godt.

b. L Der er en forbedring; og den er endda for langsom.

c. (J ) Der er en forbedring; men den er for hurtig. Det er $\mathrm{J}$ skidt/L godt.

d. L Der er en forbedring; og den er endda for hurtig.

Disse data er afslørende. Ovenfor så vi i (18) og (19), at forbedring er orienteret mod GOD, og at langsom er en AM i denne sammenhæng. Nu kan man nemt vise, at hurtigt er en RM her, så man kan konstatere, at for kan knyttes både til AMere og RMere. Ikke desto mindre gennemtvinger for i alle tilfælde en negativ konklusion helt uafhængigt af, 
hvilken type modifikator den er knyttet til. Det betyder, at for agerer på modifikatorens kvalitet og forvandler en RM til en (vender)AM. Selekteringsfunktionen er faktisk så stærk, at den annullerer alle andre modificerende og/eller kombinerende funktioner, der måtte forekomme i den ytring, for dukker op i. Følgende eksempelpar underbygger denne analyse yderligere:

(26) a. Der er for megen forbedring; det er J skidt/L godt.

b. Der er for lidt forbedring; det er J skidt/L godt.

Forbedring er godt, lidt forbedring er også godt, og megen forbedring er endda endnu bedre. Men for lidt eller for megen forbedring er skidt. Denne operator fortjente at blive undersøgt nærmere.

\subsection{Konnektorer}

Lad os til sidst kaste et blik på konnektorerne. Deres hovedfunktion er at kombinere synspunkter, dvs. argumentativitetsbidder, til en mere kompleks struktur. Struktureringsfunktionen medfører ofte en specificering af synspunktintern struktur, altså af polyfone egenskaber. Konnektorklassen er ekstremt heterogen, og der findes en omfattende sprogvidenskabelig litteratur om mange af de enkelte konnektorer - både inden for TAS og inden for andre teoridannelser. En ledende idé bag den modulære tilgang er, at indsigt fra alle disse studier vil kunne udnyttes i modellen; men det er naturligvis ikke muligt at foretage en gennemgribende argumentativ analyse af konnektorerne i denne artikel, hvor jeg må nøjes med at give en kortfattet oversigt over nogle af deres væsentligste egenskaber.

Konnektorerne kan give indikationer mht. argumentativ retning, argumentativ styrke og polyfonistruktur. Derudover kan de have ret så komplekse strukturelle egenskaber. De kan således arbejde direkte på de involverede synspunkter, eller de kan knytte sig til udsigelsen eller til udsagnet opfattet som resultatet af udsigelsen. Sommetider frembringer de endda nye strukturtræk. ${ }^{18} \mathrm{Lad}$ os se på det velkendte eksempel med men:

18 I Nølke (1996) vises det, at de to franske kausale konnektorer car (=for) og donc (= altså) går på udsigelsen og angiver et argumentationstema. Se også Nielsen (1996), hvori disse analyser appliceres $i$ et mere omfattende studium af argumentationen $i$ franske præsentationsbrochurer. 
(27) Det er vidunderligt vejr; men jeg har arbejdet hårdt hele dagen. ( $\mathrm{X}$ men $\mathrm{Y}$ )

Men arbejder på retning, styrke (kun indirekte) og polyfonistruktur. Konnektoren angiver mht. retning, at det samme topiske felt skal benyttes i konsekventen for de to topoi, der aktiveres af de to konjunkter (X og Y), men med modsat fortegn. Hvis vi kalder denne konsekvent for $\mathrm{Q}$, får vi følgende topoipar:

(28) $\mathrm{T}_{\mathrm{X}}$ : 'jo mere vidunderligt vejret er, jo mere $\mathrm{Q}$ '

$\mathrm{T}_{\mathrm{Y}}$ : 'jo mere jeg har arbejdet hele dagen, jo mindre Q'

Men angiver også, at afsender kun tager topos'et $\mathrm{T}_{\mathrm{Y}}$ på sin egen kappe. Indirekte markeres $\mathrm{T}_{\mathrm{Y}}$ derfor som stærkere end $\mathrm{T}_{\mathrm{X}}$, eftersom det skubber $\mathrm{T}_{\mathrm{X}}$ til side $\mathrm{i}$ den argumentative handling, der fremkommer. Det er de instrukser, der skyldes men. For at nå frem til en interpretation af (28) må vi imidlertid også prøve at instantiere Q. Her kan vi støtte os på de topoi, der aktiveres i sætningerne. Vi har set, at verbet at arbejde indeholder topos'et < ARBEJDE ; INDSATS/ANSTRENGELSE >, hvilket kan føre til træthed. Så 'mindre Q' kunne være en konsekvens af, at afsender er træt. En nøjagtig interpretation kan dog kun findes i en fuldstændig kontekst og ved at tage hensyn til alle de instrukser, det sproglige materiale giver. Ovenstående eksempel var da også kun ment som en illustration af, hvilken type rolle konnektorer spiller i opbygningen af denne mængde af instrukser.

Konnektorerne kan inddeles i ensrettere og modsatrettere alt efter den argumentative retning, de angiver. Men er en modsatretter, for så vidt som den kræver, at dens to konjunkter er modsat rettede. Andre eksempler på modsatrettere kunne være konnektorer som imidlertid, på den anden side set og skønt. Kausale konnektorer som fordi, for og derfor er eksempler på ensrettere. Andre eksempler på ensrettere kunne være konnektorer som endda og eller $i$ det mindste, der også påvirker den argumentative styrke:

(29) a. Søren er lige så god til bridge som Hanne, måske endda bedre.

b. Søren er lige så god til bridge som Hanne, eller i det mindste næsten lige så god.

Endda øger styrken, medens eller i det mindste svækker den.

Som det fremgår af disse få eksempler, kan konnektorerne have et væld af forskelligartede egenskaber, der synes at kunne gå i alle ret- 
ninger. Deres fundamentale funktion er og bliver dog at kombinere synspunkter, dvs. argumentativitetsbidder, for derved at skabe en mere kompleks struktur, der så kan give anledning til argumentation.

\section{Et par konklusioner}

Det er en selvfølge, at sprogligt materiale er en forudsætning for al verbal argumentation. Jeg har imidlertid prøvet at vise i denne artikel, at sproget er mere end blot en forudsætning. Faktisk kan al slags sprogligt materiale interpreteres som indikatorer for argumentativ sprogbrug. Leksikalske ord (og syntagmer) indeholder topoi, og andre ord (og syntagmer) fungerer som argumentative funktorer. Syntaksen kan medvirke til at skabe polyfonistruktur, og selv afledte strukturer som fx informationsstruktur kan undertiden påvirke argumentationen direkte. Når nu grundlæggende sprogstruktur altså åbenbart er afgørende for argumentative former og funktioner, må argumentationsbetingelserne forventes at afvige fra sprog til sprog. Komparative studier bliver derfor vigtige for forståelsen af ofte meget subtile forskelle. Det argumentative mikroniveau råber faktisk på egentlige sprogvidenskabelige undersøgelser af særlige sproglige midler med henblik på at undgå interkulturelle misforståelser fx i forretningsforhandlinger som i eksemplet citeret $\mathrm{i}$ indledningen.

En grundig viden om, hvorledes de enkelte sproglige størrelser (ord, syntagmer, strukturer osv.) fungerer, kan være afgørende for den, der argumenterer. Jeg vil derfor afslutte dette defensorat for en modulær sprogvidenskabelig tilgang til argumentationsanalyse med to anbefalinger, der knytter pragmatik og grammatik sammen:

- For at vare effektiv skal du bruge de rigtige sproglige former og strukturer.

(Dette involverer grammatisk og leksikalsk viden.)

- For at valge de effektive former og strukturer skal du skave til dit formål.

(Dette involverer viden ikke blot om de mekanismer, der styrer interpretationen, men også om de relevante parametre og deres værdier, herunder normer m.m.) ${ }^{19}$

19 Tak til Anne Ellerup Nielsen, der har læst en tidligere version af denne artikel. Jeg har haft stor glæde af at diskutere form og indhold med Anne. 


\section{Referencer}

Anscombre, Jean-Claude (1989). Théorie de l'argumentation, topoï, et structuration discursive. In Revue québécoise de linguistique 18,1. 13-56.

Anscombre, Jean-Claude (1995a). Topique or not topique : formes topiques intrinsèques et formes topiques extrinsèques. In Journal of Pragmatics 24. 115-141.

Anscombre, Jean-Claude (1995b). La théorie des topoï : sémantique ou pragmatique ? In HERMES 15-16. 181-194

Bruxelles, Sylvie, Oswald Ducrot \& Pierre-Yves Raccah (1995). “Argumentation and the lexical topical fields", Journal of Pragmatics 24. (99-114)

Ducrot, Oswald (1980). Les échelles argumentatives. Paris: les éditions de minuit.

Ducrot, Oswald (1984). Le dit et le dire. Paris: les éditions de minuit.

Ducrot, Oswald (1988). Topoï et forme topiques. In Bulletin d'études de linguistique française 22, Tokyo.

Ducrot, Oswald (1990). Argumentation et Persuasion. In Actes du Congrès d'Anvers : «Énonciation et parti-pris ».

Ducrot, Oswald (1995). Les modificateurs déréalisants. In Journal of Pragmatics 24. 145-165.

Eemeren, Frans H. van, Rob Grootendorst \& Tjark Kruiger (1987). Handbook of Argumentation Theory. Dordrecht: Foris Publications.

Garcia Negroni, Maria Marta (1995). Réinterprétation et Scalarité : les instructions de relecture dans la langue. Disputats. Paris: E.H.E.S.S.

Nielsen, Anne Ellerup (1996). Argumentationsstrategier i franske prasentationsbrochurer. Fra det sproglige til det retoriske niveau. Ph.d.-afhandling. (Handelshøjskolen i Århus)

Nølke, Henning (1992). Semantic Constraints on Argumentation. In Eemeren, Frans H. van et al. (udg.): Argumentation Illuminated. Amsterdam: Sicsat. 189-200.

Nølke, Henning (1993). Le regard du locuteur : pour une linguistique des traces énonciatives. Paris: Kimé.

Nølke, Henning (1994a). Linguistique modulaire : de la forme au sens. Louvain/Paris: Peeters.

Nølke, Henning (1994b). Informationsstruktur. Med fokus på fokus. In Hermes 13. 251-279.

Nølke, Henning (1996). A contrastive and argumentative analysis of the French connectors donc and car. In Leuvense Bijdragen 85. 313-328.

Popper, Karl (1972). Epistemology without a Knowing Subject. In Objective Knowledge. 119-122.

Raccah, Pierre-Yves (1995a). Introduction. Argumentation and natural language: Presentation and discussion of four foundational hypotheses. In Journal of Pragmatics 24. 1-16. 
Raccah, Pierre-Yves (1995b). Introduction to 'De-realising modifiers' by Oswald Ducrot. In Journal of Pragmatics 24. 147-148.

Thomsen, Christa (1998). La séquence de la requête : stratégies d'argumentation et de politesse dans les conversations d'affaires téléphoniques. Ph.d.-afhandling (Århus Handelshøjskole). 